

\section{Using individual study profiles of first-year students in two different disciplines to predict graduation time}

Telle Hailikari, Center for University Teaching and Learning, Faculty of Educational Sciences, University of Helsinki, P.O. Box 9 (Siltavuorenpenger 10), FI-00014 University of Helsinki, Finland telle.hailikari@helsinki.fi**

Reijo Sund, Institute of Clinical Medicine, University of Eastern Finland, P.O. Box 1627 (Mediteknia Building), FI-70211 Kuopio, Finland

Anne Haarala-Muhonen, Centre for University Teaching and Learning, Faculty of Educational Sciences, University of Helsinki, P.O. Box 9, FI-00014 University of Helsinki, Finland

Sari Lindblom-Ylänne, Centre for University Teaching and Learning, Faculty of Educational Sciences, University of Helsinki, P.O. Box 9, FI-00014 University of Helsinki, Finland 


\title{
Using individual study profiles of first-year students in two different disciplines to predict graduation time
}

\begin{abstract}
Despite vast research on transitioning to higher education and student diversity, little longitudinal evidence exists of how individual differences of first-year students predict their graduation times. The present study explored the relation between first-

disciplines, by following the same students' $(\mathrm{N}=65)$ study progress for six years using student records data. Profiling students was based on student interviews. Statistical analysis of time to degree completion was conducted using event history analysis. The results revealed that first-study-year study profiles clearly predict graduation times and degree completion. Disciplinary differences existed between graduation times, which may be explained by the different structures of the disciplines. The results imply that individual students need tailored support at different phases of their studies.
\end{abstract}

Keywords: first study-year; study profiles; student diversity; study progress; follow-up

\section{Introduction}

The amount of time students spend pursuing a higher education degree has been a key concern for educational developers and policy-makers over the past years in Europe (Vossensteyn and Stensaker longer than the expected 3 years for and Hovdhaugen 2014). Thus, there is a continuing interest among educational developers and policy-makers to understand the factors that affect time to graduation in

particularly decisive of future development and success at university (e.g. Gale and Parker 2014; Hultberg, Plos, Hendry, and Kjellgren 2008; Leese 2010; Tinto 1997). It has been

during the first study year are major determinants for subsequent study success in higher education (e.g., Reason, Terenzini, and Domingo, 2006). Vast research literature focuses 
on the importance of the transition to university and the challenges posed by student diversity on higher education institutions (Coertjens, Braun, Trautwein, and LindblomYlänne 2017; DeClerq, Galand, and Frenay 2016; Kyndt, Donche, Trigwell, and Lindblom-Ylänne 2017). Despite the rather active interest in the subject, rather little longitudinal research follows students' study progress from the beginning of their studies to degree completion. According to McInnis (2001), longitudinal research following cohorts of students to the completion of their first degree is needed to understand the influence of the first study year better and to meet the diverse needs of the students during the degree. Furthermore, research applying longitudinal settings are mainly quantitative in nature, primarily involving surveys (e.g., Asikainen, Parpala, Lindblom-Ylänne, Vanthournout, and Coertjens 2014; Haarala-Muhonen, Ruohoniemi, Parpala, Komulainen, and Lindblom-Ylänne 2017; Parpala, Asikainen, Ruohoniemi, and Lindblom-Ylänne 2017). Quantitative longitudinal settings certainly have their benefits but they do not necessarily reveal the whole picture regarding individual variation of firstyear students necessitating longitudinal research using both qualitative and quantitative data. Supplementing quantitative settings with qualitative data may provide a richer understanding of the phenomenon. The present study examines the relation between first-

progress for six years by using student records data. Our earlier qualitative research illustrated that first-year students greatly differ from each other regarding their motivation, interest, self-efficacy, self-regulation skills and experiences of their first study year (Lindblom-Ylänne, Saariaho, Inkinen, Haarala-Muhonen and Hailikari 2015; Lindblom-Ylänne, Haarala-Muhonen, Postareff and Hailikari 2017)). The purpose of this study is to explore how the first-

times by combining qualitative interview data of the first study year with longitudinal quantitative student records data. In doing so, we hope to deepen the understanding of how the diversity during the first study year is reflected on the graduation times.

\section{Factors influencing the study progress of first-year students}

Different theoretical perspectives allow investigation of students' study progress in higher education, for example, psychological, organisational, cultural and economic perspectives (Bosse 2015; Van den Berg and Hofman 2005; see also Kuh, Kinzie, Buckley, Bridges, and Hayek 2006). However, previous research considering all of these 
factors at different levels showed that the variance in study progress is largely determined by individual-level factors (Van den Berg and Hoffmann 2005). The present study focuses on individual-level factors influencing students' study progress, leaving out mesoand macro-

Research focusing on study progress in higher education emphasises the importance of good self-regulation and time-management skills (Asikainen, Parpala, Virtanen, and Lindblom-Ylänne 2013; Hailikari and Parpala 2014; Haarala-Muhonen, Ruohoniemi, and Lindblom-Ylänne 2011; Klassen, Krawchuk, and Rajani 2008; Krause and Coates 2008). Self-regulation of learning involves students initially setting learning goals, later regulating and monitoring their motivation, cognition, behaviour and study environment to achieve the set goals (Pintrich 2000; 2004; Zimmerman 1998). Important elements of self-regulation skills are volitional strategies, such as time and effort management (Boekaerts and Corno 2005; Corno 1993). Asikainen et al. (2013) showed that good self-regulation skills are strongly related to study success at both the initial and final years of studying: students who organise their studies, manage their time well and commit to their studies also receive higher grades. Different disciplines and different cultures report similar results (Diseth 2007; Hailikari and Parpala 2014; Krause and Coates 2008; Rytkönen et al. 2012). The importance of self-regulation skills also relate to study engagement. In their study on first-year students' engagement, Krause and Coates (2008) concluded that good self-regulation skills are an essential foundation for study engagement from the very beginning of studies. The more students engage in activities related to high-quality learning outcomes, the more successful they are. Additionally, students who can set goals in learning, take responsibility and manage their time and effort are also more likely to be successful in their studies and progress more quickly (Asikainen et al. 2014; Rytkönen et al. 2012). Self-regulation skills are especially important in non-professional fields, such as the humanities, where students often lack clear goals in studying (Mikkonen and Ruohoniemi 2011). Good management skills regarding time and effort help students to understand the usefulness of their studies (Hailikari and Parpala, 2014). Interestingly, some recent studies suggest that selfregulation skills remain rather constant throughout the studies. Parpala et al. (2017) explored the development of university students' time and effort management skills during university studies, and found they remained rather constant throughout the studies. Asikainen et al. (2014) report similar findings. 
self-regulation, is self-efficacy. Pajares (2002) claims exploring constructs, such as motivation, learning and self-regulation, is impossible without considering the role of self-efficacy. Bandura (1997) defines self-efficacy beliefs as:

to organise and execute the courses of action required to produce give

(Bandura 1997). Self-efficacy beliefs are closely intertwined with self-regulation skills, in that students who believe they can and will do well are much more likely to be motivated in terms of self-regulation, persistence, effort and engagement (Pintrich and Schunk 2002; Zimmerman 2000). Bandura (1997) suggests indirect links between academic achievement through goal-setting and self-regulation and self-efficacy beliefs. Students with high self-efficacy often cope with cognitive demands more effectively (Lane and Lane 2011), utilise meaningful learning strategies and perceive learning tasks as interesting (Greene, Miller, Crownson, Duke, and Akey 2004). Komarraju and Nadler (2013) conclude that self-efficacious people are more likely to achieve academically because they monitor and self-regulate their impulses and persist in the face of challenges. Additionally, low self-efficacy beliefs have been shown to increase stress and narrow the use of cognitive strategies, powerfully influencing student performance (Bandura and Wood 1989). Klassen, Krawchuk and Rajani (2008) found that students who procrastinate do not necessarily lack knowledge of useful strategies, but rather, lack confidence to apply these strategies in completing tasks. They referred to the belief of individuals -efficacy for self-

Self-regulation and self-efficacy beliefs are also closely related to motivation. Research literature often distinguishes between intrinsic and extrinsic motivation. Intrinsic motivation refers to being motivated by a task for its own sake and because the task itself is interesting, whereas extrinsic motivation refers to being engaged in a task because of a separate outcome or reward (Ryan and Deci 2000). Intrinsic motivation is a key contributing factor in the completion of degrees (Dewitte and Lens 2000; Mikkonen and Ruohoniemi 2011). However, motivation itself is not enough. Students with high levels of self-efficacy are more likely to demonstrate intrinsic motivation and engage in tasks (Prat-Sala and Redford 2010; Pintrich and Schunk 2002). Furthermore, students who believe in their ability to manage their studies are more likely to be motivated in terms of effort and persistence (Pintrich and Schunk 2002). 
Self-regulation skills, self-efficacy beliefs, motivation and interest are usually positively related both to each other and to the experiences of studying. At the individual level, however, they may sometimes form incoherent combinations, evident in our previous studies (Lindblom-Ylänne et al. 2015; 2017). We found variation in the combination of these factors at the individual level. To more deeply understand the variation of factors influencing study progress, our previous research compared students who were progressing either slowly or quickly in their studies and identified altogether five different student profiles. For students progressing at a slow pace, we found three distinct dilatory profiles named Procrastinators, Strategic delayers, and Unnecessarily delaying students (Lindblom et al. 2015). Regarding students studying at a rapid pace, we identified two distinct profiles which were named Strenuously progressing students and Effortlessly progressing students (Lindblom et al. 2017). These five student profiles differed from each other in terms of their self-regulation skills, self-efficacy beliefs, motivation and interest, experiences of studying and how these factors were combined at the individual level. The differences between the profiles is summarised in Table 1.

Table 1. Comparison of first-year individual study profiles $(\mathrm{N}=65)$

\begin{tabular}{l|lllll}
\hline Profiles & $\begin{array}{l}\text { Motivation } \\
\text { and interest }\end{array}$ & $\begin{array}{l}\text { Self- } \\
\text { regulation } \\
\text { skills }\end{array}$ & $\begin{array}{l}\text { Self- } \\
\text { efficacy }\end{array}$ & $\begin{array}{l}\text { Study } \\
\text { experiences }\end{array}$ & Other \\
\hline Procrastinators & Low & Weak & Low & Negative & \\
$\begin{array}{l}\text { Strategic } \\
\text { delayers }\end{array}$ & High & Strong & Strong & Positive & $\begin{array}{l}\text { Slow } \\
\text { progress due } \\
\text { to own } \\
\text { choice }\end{array}$ \\
$\begin{array}{l}\text { Unnecessarily } \\
\text { delaying } \\
\text { students }\end{array}$ & High & Weak & Average & Positive & \\
$\begin{array}{l}\text { Strenuously } \\
\text { progressing fast } \\
\text { students }\end{array}$ & Very high & $\begin{array}{l}\text { Average } \\
\text { to strong }\end{array}$ & Strong & Very positive & $\begin{array}{l}\text { Experiencin } \\
\text { g some level } \\
\text { of stress and } \\
\text { overload }\end{array}$ \\
& & & & & \\
$\begin{array}{l}\text { Effortlessly } \\
\text { progressing } \\
\text { students }\end{array}$
\end{tabular}


In the present study, we follow the study progress of these distinct study profiles for six years. In following these students, we have several expectations: Firstly, we expect that the study progress of the Effortlessly progressing students and Procrastinators remains rather constant. This expectation is based on previous studies that suggest the first study year can predict both future study success and students' self-regulation skills, with self-efficacy beliefs remaining rather constant throughout the studies (Asikainen et al 2014; Parpala et. al. 2017; Galand, Raucent, and Frenay, 2010). These profiles represented the so-called extreme cases; favourable aspects were clustered together for the Effortlessly progressing students, whereas the opposite was true for the Procrastinators. Secondly, we expect the study progress of students in the Strenuously progressing students profile would slow down. Despite the rapid study progress during the first study year, this student group described some difficulties in both timemanagement and stress already during the first study-year and the independent nature of university studying and time-management was challenging for them. Thirdly, we expect the study progress of students in the Strategic delayers profile to quicken as their studies proceed because their slow study progress during the first study year was mainly due to these own choice or prioritisation. Finally, we expect the study progress of the Unnecessarily delaying students to quicken as they adjust to the university culture and develop their self-regulation and time-management skills. These students typically had a clear intention-action gap, that is, a clear discrepancy between their own study objectives and actual study practices. We also expect disciplinary differences, as humanities and law represent different disciplinary areas. The humanities curriculum is rather flexible and students may choose different courses rather freely; the law curriculum is professional with little choice, mainly comprising compulsory courses in different areas of law.

\section{The present study}

The present study extends our previous studies that identified five different study profiles of first-year students using interviews and explored the factors that differentiated these profiles from each other (Lindblom et al. 2015; Lindblom et al. 2017). The present study -year study profiles predict their graduation times in two different disciplines: humanities and law. We explore the differences between the 
profiles in degree completion,

completion rates between the professional (law) and non-professional/generalist (humanities) degrees.

The participants of the study were originally selected based on the number of credits obtained during the first study year and deep interviewed after their first study year and, in the present study, their study progress is followed for six years.

\section{Methods}

\section{Participants}

Our sample consisted of 65 students, who were interviewed at the end of their first study year (Lindblom et al. 2015; Lindblom et al. 2017). Of these students, 40 had started their studies in humanities, having three different major subjects: Finnish, English and History, the largest subjects at the Faculty of Humanities. Studying law were 25 students. These students were not a random sample. We applied purposive sampling and the selection of students was based on the number of credits obtained during their first study year. The first sample of students $(\mathrm{n}=28)$ represented students who had progressed slowly (earning fewer than 45 credits during one academic year) during their first academic year. Out of the students who had earned fewer than 45 credits, $63 \%$ volunteered to be interviewed in humanities and $31 \%$ in law. The second sample of students represented students whose study pace had been the fastest in their study programs earning clearly more than the expected 60 credits during the first academic year. The level of participation rate was high. The sample represented $73 \%$ of the students who had earned more than 60 credits during the first academic year in both disciplines. These students were invited to the interviews after completing their first year at the university and they agreed to participate in the study.

\section{Context of the study}

The Finnish higher educational system is similar to other countries in the European Union. In Finland, the main higherare selected on the basis of a rigorous, discipline-specific entrance examination. When 
students are accepted to the university, they are given the right to enroll first to a programme. The target duration of the studies in both law and humanities is 5 years: 3 years for the degree and additional two years for programmes unless they want to change their discipline.

labour market, especially for many regulated professions requiring a m for qualification.

ECTS, in other words, five years of full-time study or 120 ECTS (2 years) after EuroEducation 2014). Law is a regulated profession and degree of Law does not qualify for the profession of lawyer or judge in Finland.

Most professional programmes qualify for a certain profession (such as law) and are pre-scheduled and structured with preset timetabled study plans. The students are adviced to follow that plan but have the right to choose how many courses they will complete during an academic year. On the other hand, generalist programmes that do not qualify for a certain profession (such as humanities) are characterised by the ethos of academic freedom and offer ample possibilities for individual paths, both in terms of study pace and selecting course modules and minors. This freedom of choice poses challenges for students in terms of the independence required from the students and the graduation times are generally longest in humanities (Vipunen database, 2018). Thus, studying at both a faster and slower pace than three plus two years is possible in both disciplines. The average graduation time in law during the last decade has been 6 to 6.5 years (Vipunen database, 2016) whereas in humanities the average graduation time for Master degree has been about 8 to 8.5 years (Vipunen database, 2018). Study time is not limited, meaning that uncompleted courses, low study success or a small number of study credits will not be penalised by rejection. However, university students in Finland receive financial support from the government for their studies. To receive this assistance, students must complete at least five study credits per month and at least 20 study credits per year of the expected 60 yearly credits.

\section{Materials}


This study obtained student records data from the University of Helsinki. We combined the records data with the profiles identified in our previous studies (Lindblom et al. 2015

to study, or extraction of records data from the Student Register. Obtained information baseline factors for the students. Median follow-up time, calculated from the start of studies, was 5.7 years. The small number of students in some profile groups led to few degree completions in these groups. Small numbers rarely meet the assumptions of statistical models; consequently, certain analyses involved combining separate profiles to form rapidly- and slowly progressing groups. Data on gender, year of birth, credits, completed courses and degrees were obtained from the Student Register of the University of Helsinki. Separate permission was applied from the register maintainer to use the records data, with consent to use student records data from participating students. As explained above, classification of students into five different profiles was based on their interviews regarding their first-year studies.

\section{Analysis}

Statistical analysis of time-to-degree completion involved event history analysis. Due to small number of events in some groups, mainly combined groups of rapid or slowly progressing students have been used in the analyses and more detailed groups only if the number of events was reasonably large for stratified analysis. Using Kaplan-Meier curves, we described the proportion of completed degrees as a function of time since the

Follow-up was until the degree completion or 5.7 years, whichever occurred first. In the latter case observations were considered right-censored. Testing differences between the groups involved log rank tests. Visualisation of study

study progression group to which a student belongs. These groups are based on the categorization of obtained sums of credits in a study year. In the visualisation, each horizontal line represents one student; lines are sorted so that similar "pathways" are next to each other, thus enhancing and simplifying the interpretations. Probability calculations for continuous rapid or slow study progression during the second study year concerned relative frequencies of staying in the same category as in the first year. 
A complete follow-up time of of 5.7 years was available for all students. This allowed the use of logistic regression analysis for assessing the relative importance of available background factors on completing or degree during the follow-up. The small number of events, that is degree completions, in some groups led to profiles under rapid or slow progression requiring being combined in some analyses to guarantee reliable estimation. Statistical software R version 3.3.3. with extension packages Survo R, survival and rms were used for the data processing and analyses.

\section{Results}

Characteristics of the 65 students are presented in Table 2, stratified by the study profiles based on interviews. Of the total students, $61.5 \%$ were women; however, relatively more men were among strategic delayers and law students than in other groups. Mean age at the beginning of studies was 22.4 years (range 18-37). Mean credits obtained during the first year correspond to definitions in which rapidly progressing students had more than 60 credits and slowly progressing fewer than 45 credits. More than $80 \%$ of students in -up time of approximately 5.7 years, while the proportion was significantly lower among slowly progressing students (Table 2, Figure 1). No significant differences were detected between the students of humanities and law on the proportion of students obtaining a -up. The only group in which more than half of the during the follow-up was the group of Effortlessly progressing students. None of the students in the Procrastinators profile obtained their -up. Strikingly, more than three times the number of law students obtained a maste

(Table 2). 
Table 2. Characteristics of the different study profiles

\begin{tabular}{|c|c|c|c|c|c|c|c|}
\hline & \multicolumn{2}{|c|}{ Rapid } & \multicolumn{3}{|c|}{ Slow } & \multirow[t]{2}{*}{ Humanities } & \multirow[t]{2}{*}{ Law } \\
\hline Student profile & $\begin{array}{l}\text { Effortlessl } \\
\text { y } \\
\text { progressin } \\
\text { g }\end{array}$ & $\begin{array}{l}\text { Strenuousl } \\
\mathrm{y} \\
\text { progressin } \\
\mathrm{g}\end{array}$ & $\begin{array}{l}\text { Strategic } \\
\text { delayers }\end{array}$ & $\begin{array}{l}\text { Unnecess } \\
\text { arily } \\
\text { delaying }\end{array}$ & $\begin{array}{l}\text { Procrasti } \\
\text {-nators }\end{array}$ & & \\
\hline $\mathbf{N}$ & 26 & 11 & 11 & 7 & 10 & 40 & 25 \\
\hline Women, \% & $57.7 \%$ & $72.7 \%$ & $36.4 \%$ & $71.4 \%$ & $80.0 \%$ & $75.0 \%$ & $40.0 \%$ \\
\hline Law students, \% & $46.1 \%$ & $18.2 \%$ & $36.4 \%$ & $71.4 \%$ & $20.0 \%$ & $0 \%$ & $100 \%$ \\
\hline $\begin{array}{l}\text { Mean age, years } \\
\text { (SD) }\end{array}$ & $\begin{array}{l}23.3 \\
(4.4)\end{array}$ & $\begin{array}{l}20.5 \\
(1.6)\end{array}$ & $\begin{array}{l}23.0 \\
(1.7)\end{array}$ & $\begin{array}{l}20.4 \\
(1.1)\end{array}$ & $\begin{array}{l}23.2 \\
(3.5)\end{array}$ & $\begin{array}{l}22.5 \\
(4.1)\end{array}$ & $\begin{array}{l}22.4 \\
(2.2)\end{array}$ \\
\hline $\begin{array}{l}\text { Mean credits } \\
\text { during the first } \\
\text { year (SD) }\end{array}$ & $\begin{array}{l}77.2 \\
(16.9)\end{array}$ & $\begin{array}{l}68.5 \\
(12.0)\end{array}$ & $\begin{array}{l}30.8 \\
(20.1)\end{array}$ & $\begin{array}{l}34.0 \\
(8.9)\end{array}$ & $\begin{array}{l}30.8 \\
(14.4)\end{array}$ & $\begin{array}{l}55.2 \\
(21.5)\end{array}$ & $\begin{array}{l}57.5 \\
(33.5)\end{array}$ \\
\hline $\begin{array}{l}\text { degree during } \\
\text { the follow-up }\end{array}$ & $88.5 \%$ & $100 \%$ & $45.5 \%$ & $71.4 \%$ & $30.0 \%$ & $72.5 \%$ & $72.0 \%$ \\
\hline $\begin{array}{l}\text { during the } \\
\text { follow-up }\end{array}$ & $57.7 \%$ & $18.2 \%$ & $18.2 \%$ & $14.3 \%$ & $0 \%$ & $15.0 \%$ & $56.0 \%$ \\
\hline Humanities & $35.0 \%$ & $22.5 \%$ & $17.5 \%$ & $5.0 \%$ & $20.0 \%$ & & \\
\hline Law & $48.0 \%$ & $8.0 \%$ & $16.0 \%$ & $20.0 \%$ & $8.0 \%$ & & \\
\hline
\end{tabular}

No statistically significant difference existed between the cumulative probability curves of the two fast-progressing student profiles, namely, Effortlessly and Strenuously progressing student profiles $(\mathrm{p}=0.59)$. Almost $90 \%$ of the students in these profiles obtained their degree during the follow-up period. Regarding the slowly progressing student profiles, during the follow-up period less than 50\% of Procrastinators or Strategic delayers completed their degree, compared to approximately $70 \%$ of Unnecessarily delaying students. Differences between the curves were not statistically significant within slowly progressing groups $(\mathrm{p}=0.26)$. 


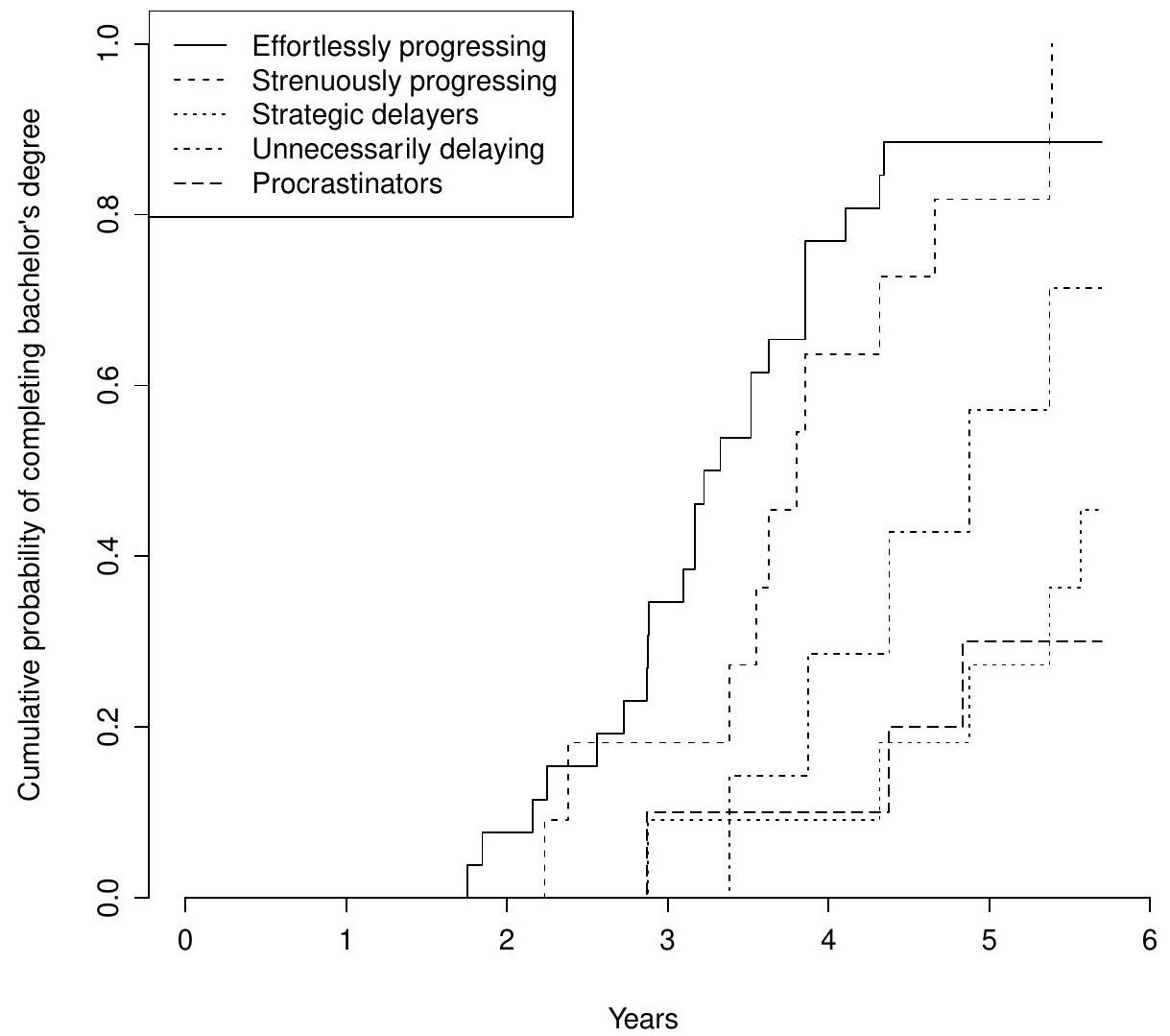

Figure 1. Cumulative proportion of completing degree between different study profiles

Examining the matrix of progress towards the degree according to completed credits by year reveals several patterns in pathways to a degree. The progress matrices are drawn separately for both rapidly (Figure 2A) and slowly progressing students (Figure 2B) but not by profiles, due to insufficient numbers of students in some groups preventing pattern formation. In these figures, each horizontal line in the matrix corresponds to a study pathway of one student (numbered in the left side of the figure), time scale has been selected so that each column corresponds to one study-year, and colour reflects the number of obtained credits (for each student and for each study-year). For example, the first line in Figure 2A indicates that the corresponding student (rapid \#37) had completed a degree during the second study year (same applies for nine first students as there are nine identical lines). Generally noticeable is the larger proportion of rapidly progressing students achieving a degree (more white colour). For example, 
most of the rapidly progressing students received their degree after three years (only seven [students rapid \#1 - \#7] have a colour other than white after third study year), while among slowly progressing students, a clearly smaller proportion received their degree after six years (students slow \#16 - \#28). Both groups also contain some mixed and unexpected profiles: some students seem to have gap years in their studies (black years in the middle of their studies; for example, student \#6 in rapid and slow groups) and in both groups, some obviously quit their studies before getting the degree (black years until the end of follow-up; for example, student \#1 in rapid and slow groups).

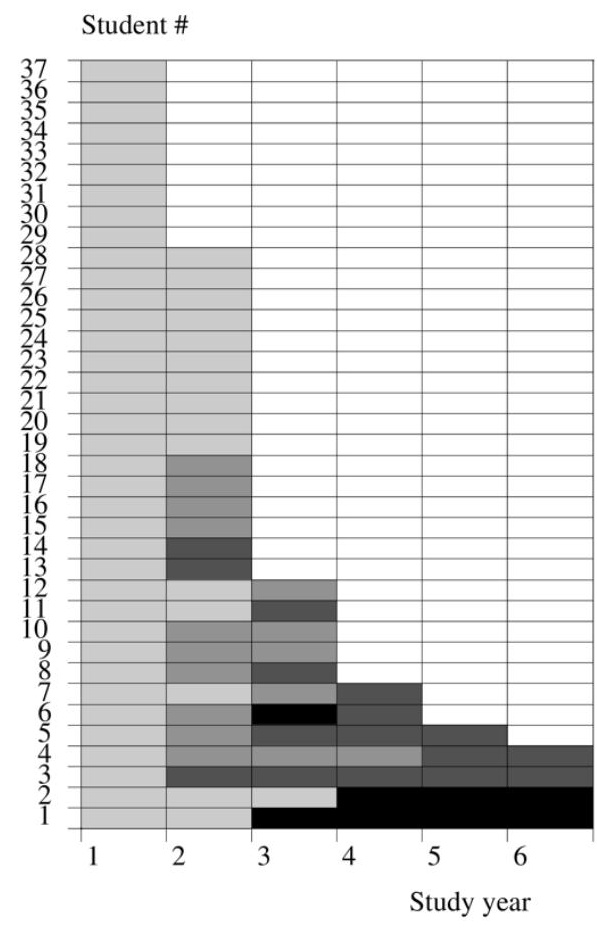

A. Rapidly white $=$ completed bachelor degree, light gray= rapid $(>60 \mathrm{cr})$, middle gray=mediocre $(45-60 \mathrm{cr})$, dark gray $=$ slow $(<45 \mathrm{cr})$, black $=$ no studies $(0 \mathrm{cr})$

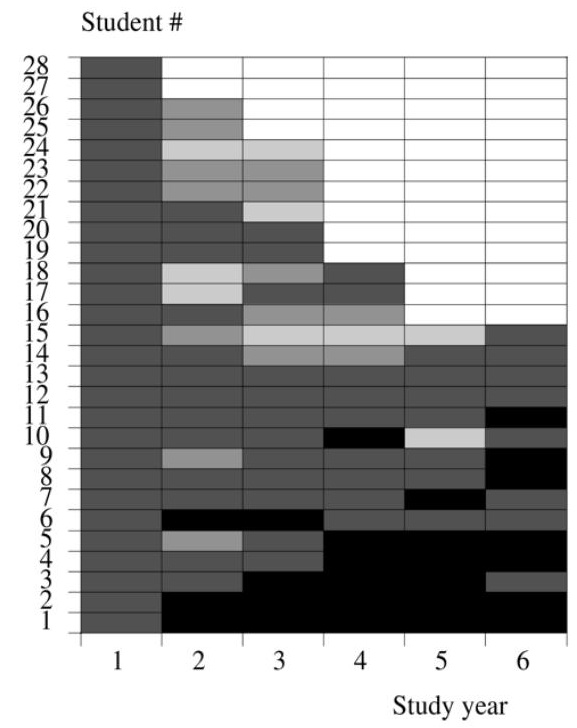

B. Slowly progressing

Figure 2. Progress of students by study year.

during the second study year is 65\% (24/37) for students who were rapidly progressing during the first year, and only $18 \%$ (5/28) for those progressing slowly during the first year. Corresponding probabilities for completing fewer than 45 credits during the second study year is $8 \%$ (3/37) for those who were rapidly progressing and $57 \%(16 / 28)$ for slowly progressing. 
For completion of a

degree, a statistically significant difference appears between Effortlessly progressing student profile and other student profiles (Figure 3). Among Effortlessly progressing students, more than 50\% had completed their degree within the follow-up, while the curve for Strenuously progressing students parallels the slowly progressing group, having only a few completions. Estimation of the curve required combining students with slowly progressing profiles into one category, due to the small number of degree completions.

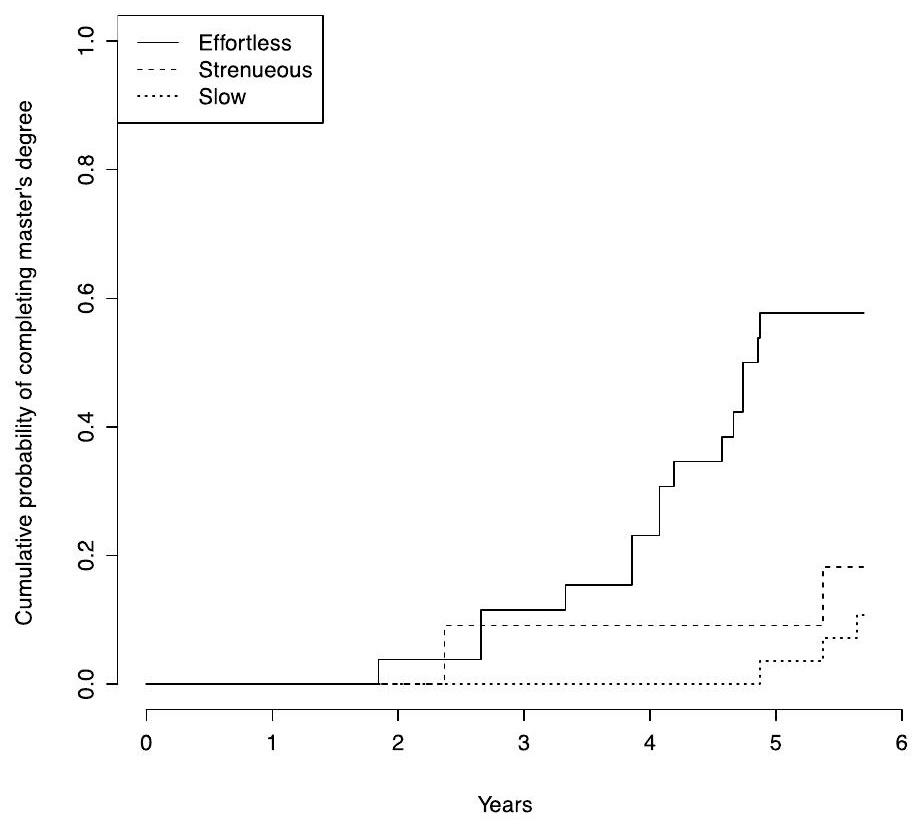

Figure 3. Cumulative proportion of completing degree between rapidly (Effortless and Strenuously progressing) and slowly progressing students

Investigating differences between students in the humanities and law revealed similar cumulative probability curves for completing degrees $(\mathrm{p}=0.88)($ Figure $4 \mathrm{a})$. However, obvious differences related to completing a degree $(\mathrm{p}=0.00012)$ (Figure 4b). Using the date of completion of a degree as a starting point (i.e. by adopting the idea that degree studies start only after completion of degree), the differences between humanities and law reveal that all law students had completed their degree in three years after completing the degree. This is not true among humanities students, with clearly different curves $(p<0.0001)$ (Figure 4c). Additional stratification by profiles was not reasonable as it resulted in a 
large number of curves with large uncertainty due to small numbers of degree completions (especially for completing degrees).

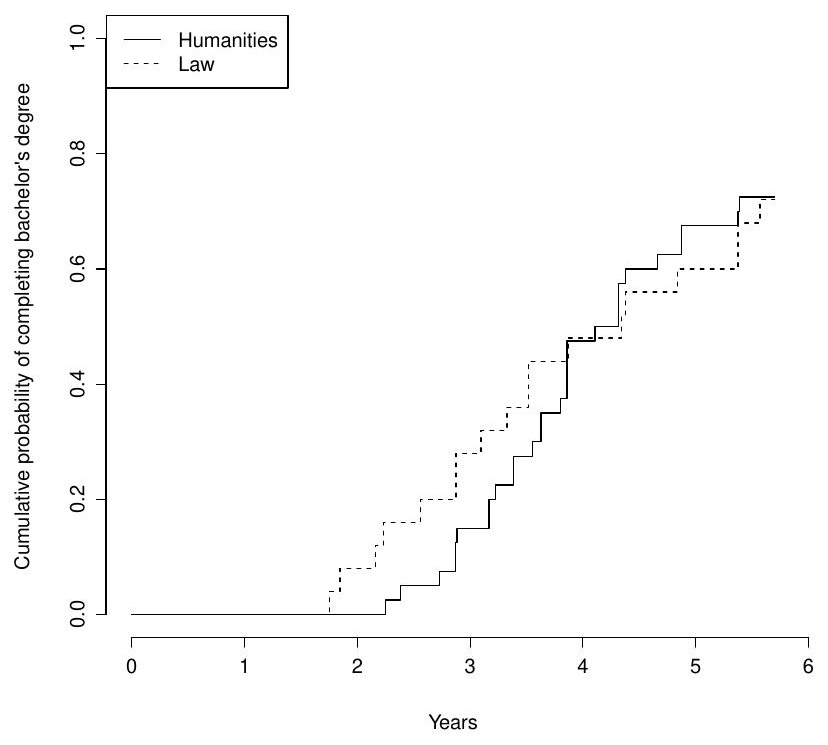

A
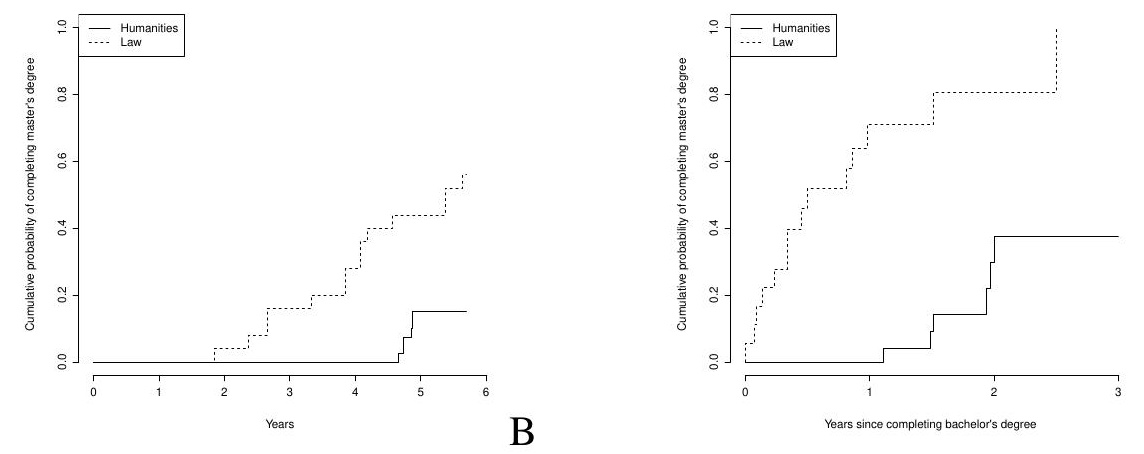

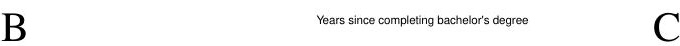

Figure 4. Cumulative proportions of completing degrees between humanities and law students. Cumulative probabilities for completing A) degree or B) degree calculated from the beginning of studies and C) from the date of completion degree.

Similar results can also be seen from the Odds Ratios (OR) reported in Table 3. Rapidly progressing students completed the degree with several times higher probability than the slowly progressing ones.

degree during the 5.7 years of follow-up as humanities students, but law students were much more likely to complete also their maste particularly strong associations were seen for gender or age in students of 25 
years or more appeared to have a higher likelihood for completing during the follow-up than the younger ones even though the associated uncertainty was large (OR 3.4, 95\% confidence interval 0.96-12, $\mathrm{p}=0.058$ ).

Table 3. Odds Ratios for completing degree during the follow-up time

\begin{tabular}{|c|c|c|c|c|}
\hline & Odds ratio & $\begin{array}{l}95 \% \mathrm{CI} \\
\text { (p-value) }\end{array}$ & Odds ratio & $\begin{array}{l}95 \% \mathrm{CI} \\
\text { (p-value) }\end{array}$ \\
\hline $\begin{array}{l}\text { Rapid progression } \\
\text { (vs. slow progression) }\end{array}$ & 11 & $\begin{array}{l}2.8-45 \\
(0.00069)\end{array}$ & 6.1 & $\begin{array}{l}1.6-24 \\
(0.0089)\end{array}$ \\
\hline $\begin{array}{l}\text { Law students } \\
\text { (vs. Humanities students) }\end{array}$ & 0.96 & $\begin{array}{l}0.31-2.9 \\
(0.94)\end{array}$ & 6.7 & $\begin{array}{l}2.1-21 \\
(0.0015)\end{array}$ \\
\hline $\begin{array}{l}\text { Females } \\
\text { (vs. Males) }\end{array}$ & 1.9 & $\begin{array}{l}0.63-5.6 \\
(0.25)\end{array}$ & 0.51 & $\begin{array}{l}0.17-1.5 \\
(0.22)\end{array}$ \\
\hline $\begin{array}{l}\text { Age } 25+ \\
\text { (vs. Age less than 25) }\end{array}$ & 0.79 & $\begin{array}{l}0.21-3.0 \\
(0.73)\end{array}$ & 3.4 & $\begin{array}{l}0.96-12 \\
(0.058)\end{array}$ \\
\hline
\end{tabular}

\section{Discussion}

The present study aimed at exploring how individual study profiles of first year students predict graduation times in two different disciplines, humanities and law. We combined longitudinal records data with the study profiles identified in our previous studies (Lindblom et al. 2015; 2017). These study profiles clearly differed from each other in several central factors found in previous studies, that is, motivation, self-regulation skills, self-efficacy and study experiences, influencing the study progress of higher-education students. The present study, firstly, explored the differences in graduation times between

differences between the two different disciplines. 
Our expectations were generally supported, and the results revealed clear differences in graduation times between the study profiles. Students with a slow study progress during the first year of studies were less likely to complete their degrees in due time compared to students who had progressed quickly in their first-year studies. Students having problems during the first year, especially in terms of study progress, appear prone to delayed graduation. Haarala-Muhonen et al. (2017) found a similar result. Students who proceeded quickly during their first study year, however, continued to work quickly: more than $80 \%$ of students in the rapidly progressing group achieved a during the follow-up time. Our result emphasises the importance of developing good study practices, especially good time-management and organisation skills, from the very beginning of studies to support the timely completion of degrees. It has been shown that students with good self-regulations skills are often better equipped to overcome obstacles they may confront later in their studies (Hailikari and Parpala 2014; 2016).

Interestingly, when looking at differences between profiles, we found some unexpected results. We had expected that the study progress of students in the Strategic delayers profile would speed up as the studies proceed. This expectation related to the slow progress during these first study year being mainly due to their life situations or their own prioritisation. Surprisingly, this study profile remained the slowest, along with the Procrastinators-profile. Less than $50 \%$ of the students in these two profiles had completed their degree in six years, which is a worrying result. Drawing conclusions about the reasons for these differences is not possible within the scope of this research; however, the reasons for the slow progress are probably different between these profiles. Students in the Procrastinators profile experienced severe challenges already during their first study year, with many unfavourable aspects of studying clustering together: low motivation, low self-efficacy beliefs and weak self-regulation skills. These students would have required special attention and support from the very beginning of their studies. Students in the Strategic delayers profile possibly found it difficult to find focus in their studies. This type of difficulty is especially challenging in the field of humanities, which is characterised by academic freedom, requiring a great deal of independence (e.g., Elvo and Pajala 2002). Beneficial to students in the Strategic delayers profile may have been a support system to help them both address these challenges and identify their future goals and interests (e.g., Lens and Vansteenkiste 2012). The study progress of students in the Unnecessarily delaying profile appears to increase as the students proceed as we expected. Students in this study profile had possibly not yet 
adjusted to the independent study culture of university after their first year; despite this, it appears they developed their self-regulation and time-management skills as their studies proceeded. For most students, the transition to the independent learning culture at university is challenging at the beginning of studies, with time needed to develop the relevant skills to cope with the new environment (Christie et al. 2013; McMillan 2014).

Another interesting finding relates to the difference between the two quickly progressing profiles. While these profiles were similar until the completion of a degree, the completion of a degree in the Strenuously progressing profile dropped to the level of slowly progressing profiles. This drop may link to the strain these students experienced in their first year and the difficulties in regulating their learning, despite their rapid study progress. These difficulties possibly became too stressful as studies proceeded and consequently, these students were unable to maintain the rapid study pace, especially in their studies. This corresponds with SalmelaAro and Read (2017), who propose that higher-education study-related exhaustion usually increases with study years. If study-related stress is already high during the first study year, the student might start to tire during studies. As Salmela-Aro and Read (2017) suggest, study programs need to pay attention to students' well-being and incorporate support systems to help students address these issues and find ways to seek help.

The results of the present study clearly reveal how diversity during the first study year is reflected in future study progress. The probability of remaining in a rapidly (or slowly) progressing group during the second study year was only around $60 \%$. More than one-third of students could not keep up the rapid (or slow) pace two years in a row. This result reflects the relatively large role of external factors on study progression. In addition, the short-term study context may impact study progression; for example, the second year of studying is possibly more demanding academically, requiring more work than the first year.

We also found large differences in completion rates of degrees between professional (law) and non-professional (humanities) fields. For humanities students, the degree completion times were especially long. No difference was seen in time to completion of degree between these two disciplines; differences started to emerge in degree studies. All law students could complete their studies, while only a few students of humanities achieved their degree in six years. This disparity may be explained by the difference between the disciplines and their structure. 
In law, a

degree is needed to obtain a qualification; consequently, a

degree is only an interim goal for them. In addition, law students study according to a rather clear pre-scheduled study plan; however, in the field of humanities, every student has the freedom and responsibility to plan their own studies. This sort of study environment requires good self-management; for some students, this is challenging. Distinctive features of the field of humanities is the lack of clear future goals, and openended career prospects (Mikkonen, Ruohoniemi and Lindblom-Ylänne 2011). These features may cause humanities students to prolong their studies due to a fear of unemployment (Mikkonen 2012). Law students can take level courses before they have completed their degree, which is not possible for humanities students. Thus, some law students might postpone taking their degree until their Master level studies are almost complete. These differences between the degrees may partly explain the apparent differences in Figure 4.

Along with the benefits of our study are some limitations. Limited possibilities of statistical analyses related to the inclusion of only interviewed students in the data, which reduced the sample size to only 65 students. Because of data limitations we considered only the baseline covariates in the analyses even though the rapid-progression of a student may vary in time as many of the factors discussed above, such as motivation, self-efficacy beliefs, self-regulation, time-management skills, short-term study context and external factors, are likely to change in time and could be included as time-dependent covariates to the analyses if data would be available. In addition, these students were not a random sample, but a selection of students who had progressed either rapidly or slowly during their first study year and agreed to participate in the study. Consequently, the results reflect certain extremes and may not be generalised automatically to the average situation. Differences in degree completion times between students who were progressing slowly or rapidly during their first study year are expected, as this first year also counts in credits required for the degree. However, looking at both sides of the distribution of obtained credits during the first study year will likely reveal a large variation of study pathways. Consequently, an average progression may be similar to the real average. This interpretation is supported by a sensitivity analysis, involving calculation of degree completions for all humanities students with same main subjects. The resulting cumulative probability curve was virtually the same as for the interviewed students (data not shown). 
To conclude, the present study showed that different first-year study progression profiles systematically predicted study success in a long follow-up. The results support the classification of five different study profiles identified in our previous studies, the classifications appearing theoretically sound. This rare combination of qualitative and quantitative data, analysed with event-history methods, allowed us to produce novel findings in many respects. The results imply that first-year study progression profiles clearly affect study success. Therefore, efforts to address students' challenging situations regarding studying and motivation, as well as self-efficacy and well-being, must begin early in the higher-education process. Useful to study programs would be the incorporation of study-counselling practices to help identify and diagnose different student profiles and support them at different phases of their studies. Evidence exists that supporting awareness of the strengths and weaknesses of their study practices involves employing inventories at different phases of the studies (Parpala and LindblomYlänne 2012). Based on responses, one possibility involves helping students develop their own ability to organise their studies or generally reflect on their study practices. Study programs should incorporate different support systems at different phases of the studies to help students address these issues and find ways to seek help.

\section{References}

Asikainen, H., A. Parpala, V. Virtanen, and S. Lindblom-Ylänne. 2013. The relationship between student learning process, study success and the nature of assessment: A Studies in Educational Evaluation 39(4): 211217. doi:10.1016/j.stueduc.2013.10.008.

Asikainen, H., A. Parpala, S. Lindblom-Ylänne, G. Vanthournout, and L. Coertjens. 2014. The development of approaches to learning and perceptions of the teachinglearning environment during bachelor level studies and their relation to study Higher Education Studies 4(4): 24 36. doi: 10.5539/hes.v4n4p24

Bandura, A. 1986. Social foundations of thought and action: A social cognitive theory. London: Prentice Hall.

Bandura, A. 1997. Self-efficacy: The exercise of control. New York: W.H. Freeman. 


\section{Zeitschift für Hochschulentwicklunersity for the first-year Zeitschrift für Hochschulentwicklung $\quad 10(4): \quad 4566$.}

Retrieved 29.3.2018 from http:// www.zfhe.at/index.php/zfhe/article/view/853.

Christie, H., P. Barron, and N. D'Annunzio-

in transition:

Studies in Higher Education 38(4): 623 637. doi:

10.100/03075079.2011.588326.

Coertjens, L., T. Brahm, C. Trautwein, and S. Lindblom-Ylänne.

transition into higher education from an

Higher Education

73(3): 357-369. doi: 10.1007/s10734-016-0092-y.

-laid plans: Modern conceptions of volition and educational Educational researcher 22(2): 14-22. doi: 10.3102/0013189X022002014.

DeClerq, M., B. Galand, and M. Frenay.

a person centered

European Journal of Psychology

of Education 32(1): 39-59. doi: 10.1007/s10212-016-0298-5.

Dewitte, S., and

nternational Journal of Educational Research 33: 733-750. doi: 10.1016/S0883-0355(00)00047-1.

Diseth, ̊. 2007.

approaches to learning, and academic

Scandinavian Journal of Educational Research 51(2): 185 204. doi: 10.1080/00313830701191654.

Elvo, N., and S. Pajala. 2002. Humanistien opiskelupolut tilastojen takana [Humanities Otus (Research Foundation of the Finnish

Student Unions) 23. Helsinki: University Press.

EuroEducation.net. 2014. Finland - Higher Education

Directory. European Union. Accessed October 11, 2018. http://www.euroeducation.net/prof/finco.htm.

Galand, B., B. Raucent, and M. Frenay

-regulation, study strategies, and motivational believes in traditional and problem-based International Journal of Engineering Education 26: 523 534. doi:

10.1080/03075079.2012.721351.

Studies in Higher Education 39: 734 753. doi: 
Greene, B. A., R. Miller, M. Crowson, B. Duke, and K.

cting high

Contemporary Educational Psychology 29: 499 517. doi:

10.1016/j.cedpsych.2004.01.006.

Haarala-Muhonen, A., M. Ruohoniemi, A. Parpala, E. Komulainen, and S. LindblomYlänne. 2017. How do the different study profiles of first-year students predict their 949-962. doi: 10.1007/s10734-016-0087-8.

Higher Education 74(6):

Hailikari, T. K., and A. Parpala.

interrelation between approaches to learning, factors influencing study progress and $10.1080 / 13562517.2014 .934348$

$$
\text { Teaching in Higher Education 19(7): 812-824. doi: }
$$

Hultberg, J., K. Plos, G.D. Hendry, and K.I. Kjellgren

Journal of Further and Higher Education 32: 47 57. doi: 10.1080/03098770701781440

Klassen, R. M., L.L.

Academic procrastination of undergraduates: Low self-efficacy to self-regulate predicts higher levels of Contemporary Educational Psychology 33: 915 931. doi: 10.1016/j.cedpsych.2007.07.001.

Klingsieck

European Psychologist 18(1): 24 34. doi:10.1027/1016-9040/a000138.

Komarraju

-efficacy and academic achievement: Why do Learning and Individual Differences

25: 67-72. doi: 10.1016/j.lindif.2013.01.005.

Krause, K.-

-year

Assessment and Evaluation in Higher Education 33(5): 493-505. doi: $10.1080 / 02602930701698892$.

Kuh, G. D., J. Kinzie, J.A. Buckley, B.K. Bridges, and J.C. Hayek. 2006. What Matters to Student Success: A Review of the Literature Commissioned Report for the National Symposium on Postsecondary Student Success: Spearheading a Dialog on Student Success. National Postsecondary Education Cooperative (NPEC).

Kyndt, E., V. Donche, K. Trigwell, and S. Lindblom-Ylänne. 2017. Higher Education Transitions Theory and Research. Abingdon: Routledge. 
Lane, J., and A. Lane. 2001. -efficacy and academic Social Behavior and $\quad$ Personality $\quad$ 29: $\quad 687$ 693. doi: 10.2224/sbp.2001.29.7.687.

into higher Journal of Further and Higher Education 34: 239 251. doi: $10.1080 / 03098771003695494$.

Lens, W., and M. Vansteenkiste -Regulated Learning: A Motivation and Self-Regulated Learning. Theory, Research and Applications, edited by D. H. Schunk and B. J. Zimmerman, 111 139. New York: Routledge.

Lindblom-Ylänne, S., A. Haarala-Muhonen, L. Postareff, and T. Hailikari. 2016. of individual study paths of successful first-year students: an interview European Journal of Psychology of Education 32(4): 687-701.doi: 10.1007/s10212-016-0315-8.

Lindblom-Ylänne, S., E.J. Saariaho-Räsänen, M. Inkinen, A. Haarala-Muhonen, and T. Hailikari.

10.14786/flr.v3i2.154.

Frontline Learning Research 3(2): 47-62. doi:

-year experience: Where

Higher

Education Research and Development 20(2): 105-114. doi:10.1080/07294360125188.

Higher Education Research \& Development 33: 1123

1135. doi: 10.1080/07294360.2014.911250.

Mikkonen, J. 2012. Interest in University Studies. Its Role and Relation to Other Motivational Variable

Behavioural Sciences,

Studies in Educational Sciences 243.

Mikkonen, J., and M. Ruohoniemi. How do veterinary students' motivation and 304. doi: 10.3138/jvme.38.3.298.

Journal of Veterinary Medicine 38: 293-

Mikkonen, J., M. Ruohoniemi, and S. Lindblom-Ylänne. 2011. The Role of Individual

Education 5: 1 16. doi: 10.1080/03075079.2011.

Studies in Higher

Pajares

-efficacy in self-

Theory

into practice 41(2): 116-125. doi: 10.1207/s15430421tip4102_8. 
Parpala, A., and S. Lindblom-Ylänne. 2012. Using a research instrument for developing Quality in Higher Education 18(3): 313-328. doi: 10.1080/13538322.2012.733493.

Parpala, A., H. Asikainen, M. Ruohoniemi, and S. Lindblom-Ylänne. 2017 relationship between the development of time and effort management and experiences of the teaching-learning environment in a un Learning and Change 9(2): 170-184. doi: 10.1504/IJLC.2017.084594. International Journal of

Parpala, A., S. Lindblom-Ylänne, E. Komulainen, T. Litmanen, and L. Hirsto. 2010. Students' approaches to learning and their experiences of the teachinglearning British Journal of Educational Psychology 80(2): 269-282. doi: 10.1348/000709909X476946.

Pintrich, P.R. 2000. The role of goal-orientation in selfin Handbook of self-regulation, edited by M. Boekaerts, P.Pintrich, \& M.Schneider, 451-502. New York: Academic Press.

Pintrich

Motivation in education: Theory, research and application (2nd ed), edited by $\mathrm{P}$. R. Pintrich \& D. H. Schunk, 190 242. Englewood Cliffs, NJ: Simon \& Schuster.

Pintrich

407. doi:

Educational psychology review 16(4): 385-

Prat-

-efficacy, doi: 10.1348/000709909X480563.

British Journal of Educational Psychology 80: 283305.

Reason, R. D., P.T. Terenzini

149 175. doi: 10.1007/s11162-005-8884-4.

Research in Higher Education 47(2):

-determination theory and the facilitation of intrinsic motivation, social development, and wellAmerican Psychologist 55: 68 78. doi: 10.1037/0003-066X.55.1.68.

Rytkönen, H., A. Parpala, S. Lindblom-Ylänne, V. Virtanen, and L. Postareff. 2012. Factors affecting biosc Instructional Science 40: 241 256. doi: 10.1007/s11251-011-9176-3.

Salmela-

10.1016/j.burn.2017.11.001.

Burnout Research 7: 21-28. doi: 
Scalon

are just lost in a crowd: forming a student identity in the first-year transition to Journal of Youth Studies 10: 223 241. doi: 10.1080/13676260600983684.

-regulatory Educational Psychologist 32: 195-208. doi: 10.1207/s15326985ep3204_1.

Arts and

Humanities in Higher Education 2 (1): 90-98. doi: 10.1177/1474022203002001008.

Thomas, L., and E. Hovdhaugen

student completion and noncompletion of the programmes in Europe: a comparative 470. doi: 10.1111/ejed.12093.

European Journal of Education 49(4): 457

$10.2307 / 2959965$

Journal of Higher Education 68(6): 599 623. doi:

Van den Berg, M. and W. Hoffman.

Multi-Measurement Study of the Impact of Student and Faculty Factors on Study Higher Education 50: 413 446. doi: 10.1007/s10734-004-6361-1

Van Dinther, M., F. Dochy

Educational Research Review, 6(2), 95-108. doi:

10.1016/j.edurev.2010.10.003.

Vossensteyn, H., and B. Stensaker.

of the European Union.

Luxembourg: Publications Office

$10.1080 / 00461520.1998 .9653292$

Educational Psychologist 33(2-3): 73-86. doi:

Educational Psychology, 25, 82 91. doi:10.1006/ceps.1999.1016. 